\title{
KAJIAN KUAT DESAK DAN MODULUS ELASTISITAS BETON MUTU TINGGI DENGAN BAHAN TAMBAH ACCELERATOR MENGGUNAKAN ANALISIS MIKROSTRUKTUR
}

\author{
Wibowo $^{1)}$, Endah Safitri ${ }^{2)}$, Frezha Nur Septian $^{3)}$ \\ 1), 2) Pengajar Prodi Teknik Sipil, Fakultas Teknik, Universitas Sebelas Maret \\ 3) Mahasiswa Prodi Teknik Sipil, Fakultas Teknik, Universitas Sebelas Maret \\ Jl. Ir. Sutami 36A, Kentingan Surakarta 57126; Telp 0271-634524. \\ Email: frezhans@gmail.com
}

\begin{abstract}
Buildings with the concept of shared use require a main structure that are strong and durable. One important factor is the use of concrete that has good strength and quality. Innovations need to be developed to find concrete that are not only strong and durable but also easy to process and fast in process of setting and hardening. One of the concrete innovations is High Strength Concrete (HSC) using added admixtures of accelerators. Accelerator is useful for accelerating the setting process and increasing the compressive strength of concrete at an early age. This study aims to examine compressive strength and modulus of elasticity of high strength concrete with accelerator addition with level used is $2 \%$ of the weight of cement using microstructure analysis at 7, 14, 21, and 28 days. The research starting from aggregate testing, compressive strength testing, modulus of elasticity testing and microstructure testing. Compressive strength testing was carried out using Universal Testing Machine (UTM). Microstructure testing was carried out by surface area analysis (SAA) method. The test object used is cylindrical with a diameter of $7.5 \mathrm{~cm}$ and a height of $15 \mathrm{~cm}$. The percentage of the increase in the compressive strength average in concrete with accelerator addition compared to concrete without any addition at 7, 14, 21 and 28 days are 26.08\%; 21.71\%; 17.49\% and 28.49\%. The percentage of the increase in the modulus elasticity value at 7, 14, 21 and 28 days are $8.97 \% ; 7.63 \% ; 6.31 \%$ and $10.13 \%$. The percentage decrease in pore volume values at 7, 14, 21 and 28 days were respectively $17.24 \% ; 17.86 \% ; 12.50 \%$ and $22.73 \%$.
\end{abstract}

Keywords: accelerator, high strength concrete, microstructure, modulus elasticity, surface area analysis.

\begin{abstract}
Abstrak
Bangunan dengan konsep penggunaan bersama memerlukan struktur yang kuat dan tahan lama. Salah satu faktor pentingnya adalah penggunaan beton yang memiliki kekuatan dan kualitas baik. Perlu dikembangkan inovasi beton yang bukan hanya kuat dan tahan lama namun juga mudah pengerjaannya dan cepat dalam proses pengeringan dan pengerasan. Salah satu inovasinya adalah beton mutu tinggi (High Strength Concrete - HSC) menggunakan bahan tambah accelerator. Accelerator berfungsi mempercepat pengikatan dan meningkatkan kuat tekan pada umur awal. Penelitian ini mengkaji kuat desak dan modulus elastisitas beton mutu tinggi dengan bahan tambah accelerator dengan kadar 2\% dari berat semen menggunakan analisis mikrostruktur pada umur 7, 14, 21, dan 28 hari. Penelitian dilakukan mulai dari pengujian agregat, kuat desak, modulus elastisitas dan mikrostruktur. Pengujian kuat desak menggunakan Universal Testing Machine (UTM). Pengujian mikrostruktur menggunakan metode Surface Area Analysis ( $S A A)$. Benda uji berbentuk silinder diameter 7,5 cm dan tinggi 15 $\mathrm{cm}$. Persentase kenaikan kuat desak rata-rata beton dengan bahan tambah accelerator terhadap beton tanpa bahan tambah pada umur 7, 14, 21 dan 28 hari adalah 26,08\%;21,71\%; 17,49\% dan 28,49\%. Persentase peningkatan nilai modulus elastisitas pada umur 7, 14, 21 dan 28 adalah 8,97\%; 7,63\%; 6,31\% dan 10,13\%. Persentase penurunan nilai volume pori pada umur 7, 14, 21 dan 28 adalah 17,24\%; 17,86\%; 12,50\% dan 22,73\%.
\end{abstract}

Kata Kunci : accelerator, beton mutu tinggi, mikrostruktur, modulus elastisitas, surface area analysis.

\section{PENDAHULUAN}

Dunia konstruksi di Indonesia terus mengalami perkembangan seiring dengan tingginya permintaan akan infrastruktur. Sementara itu, desain-desain bangunan tinggi dengan konsep penggunaan bersama semakin ramai diminati oleh para investor. Bangunan tinggi harus memiliki struktur yang kokoh, kuat dan tahan lama. Faktor penting yang harus diperhatikan adalah penggunaan beton yang mempunyai kekuatan dan kualitas yang baik. Kekuatan beton dinyatakan dalam nilai MPa yang disebut dengan nilai kuat desak. Semakin tinggi nilai MPa yang dihasilkan maka semakin tinggi juga kekuatan dari beton tersebut. Beton dengan nilai kuat desak tinggi disebut 
beton mutu tinggi atau high strength concrete (HSC). Syarat beton mutu tinggi adalah memiliki kuat desak lebih tinggi atau sama dengan $41,4 \mathrm{MPa}$.

Dewasa ini banyak penelitian tentang penggunaan bahan tambah (admixtures) sebagai penambah material utama dalam pembuatan beton mutu tinggi. Ada dua jenis bahan tambah (admixtures) yang sering digunakan yaitu, bahan tambah mineral (mineral admixtures) dan bahan tambah kimia (chemical admixtures). Pada penelitian ini penulis menggunakan bahan accelerator sebagai bahan tambah kimia (chemical admixtures) dalam pembuatan campuran beton mutu tinggi. Accelerator sering digunakan untuk mempercepat proses pengikatan dan pengerasan beton demi mendapatkan kekuatan awal beton yang tinggi. Biasanya digunakan untuk pengerjaan jalan, dan digunakan juga untuk pengerjaan struktur yang memerlukan pengerasan segera seperti pekerjaan slab dan basement. Penggunaan accelerator juga dapat mengurangi penggunaan air sampai 15\% serta mengurangi keropos pada beton. Selain itu, digunakan juga superplasticizer untuk meningkatkan workabilititas beton.

Pada penelitian ini akan dilakukan perbandingan mikrostruktur antara beton normal terhadap beton inovasi dengan penambahan accelerator dengan metode Surface Area Analysis (SAA). Surface Area Analysis (SAA) merupakan metode pengujian untuk mengukur luas permukaan, porositas dan properti isotherm dari pertambahan massa dari adsorpsi suatu gas pada suatu bahan. Hasil dari penelitian ini adalah analisis kuat desak dan modulus elastisitas beton mutu tinggi dengan bahan tambah accelerator menggunakan analisis mikrostruktur.

\section{TINJAUAN PUSTAKA}

Beton adalah campuran semen portland atau semen hidrolis lainnya, agregat halus, agregat kasar, dan air, dengan atau tanpa bahan tambah (admixture atau additive) (SNI 2847-2013). Seiring dengan pertambahan umur, beton akan semakin mengeras dan akan mencapai kekuatan ( $\mathrm{f}$ c) puncak pada usia 28 hari.

Beton mutu tinggi atau high strength concrete (HSC) adalah beton yang memiliki kuat desak yang disyaratkan lebih besar atau sama dengan 41,4 MPa (SNI 03-6468-2000). Beton mutu tinggi dengan nilai kuat desak $55-70 \mathrm{MPa}$ telah dapat diproduksi oleh produsen ready-mix, sedangkan beton dengan nilai kuat desak hingga $100 \mathrm{MPa}$ atau lebih dapat diproduksi di laboratorium.

Accelerator merupakan bahan tambah (admixture) yang masuk dalam tipe C (Accelerating Admixtures) menurut ASTM C 494. Keuntungan menggunakan bahan accelerator antara lain: mempercepat waktu setting, mengurangi penyusutan, memiliki adhesi yang baik, dan memiliki kekuatan awal serta kuat desak yang tinggi (PT. Sika Indonesia, 2017). Penambahan accelerator dapat membantu untuk memperoleh kuat desak yang tinggi dengan cepat. Hal ini dikarenakan $\mathrm{CaCl}_{2}$ (kalsium klorida) yang terdapat dalam accelerator dapat mempercepat hidrasi dari $\mathrm{C}_{2} \mathrm{~S}$ dan $\mathrm{C}_{3} \mathrm{~S}$ yang merupakan senyawa dalam beton yang memiliki sifat perekat (Nugraha, 2007).

Kuat desak beton adalah besarnya beban per satuan luas, yang menyebabkan benda uji beton hancur bila dibebani dengan gaya desak tertentu, yang dihasilkan oleh mesin desak (SNI 1974-2011). Nilai kuat desak beton dapat dihitung dengan Persamaan [1].

$f^{\prime} c=\frac{P}{A}$

Dimana:

$f^{\prime} c=$ Kuat desak beton $(\mathrm{MPa})$

$\mathrm{P} \quad=$ Gaya desak $(\mathrm{N})$

A $\quad=$ Luas penampang benda uji $\left(\mathrm{mm}^{2}\right)$

Modulus elastisitas adalah perbandingan dari desakan yang diberikan dengan perubahan bentuk per-satuan panjang, sebagai akibat dari desakan yang diberikan (Murdock dan Brook, 1999). Pengujian modulus elastisitas bertujuan mengetahui sifat elastis suatu bahan yang berkaitan erat dengan pengujian kuat desak. Untuk menghitung modulus elastisitas ada beberapa persamaan yang digunakan, diantaranya:

1. ASTM C469

$$
E c=\frac{0,4 f^{\prime} c-\sigma_{1}}{\varepsilon_{0,4 f^{\prime} c}-\varepsilon_{1}}
$$

2. Eurocode 2-1992 


$$
E c=\frac{0,4 f^{\prime} c}{\varepsilon_{0,4 f^{\prime} c}}
$$

3. ACI Committee 363-10

$E c=3320 \sqrt{f^{\prime} c}+6900$

4. SNI 2847-2013

$E c=0,043 w_{c}^{1,5} \sqrt{f^{\prime} c}$ untuk $1500<\mathrm{w}_{\mathrm{c}}<2500 \mathrm{~kg} / \mathrm{m}^{3}$

Dimana:

$\mathrm{Ec} \quad=$ Modulus elastisitas beton (MPa)

$\mathrm{f}^{\prime} \mathrm{c}=$ Kuat desak beton $(\mathrm{MPa})$

$\varepsilon_{1} \quad=$ Regangan aksial saat $0,00005(\mathrm{~mm} / \mathrm{mm})$

$\sigma_{1} \quad=$ Tegangan yang berhubungan dengan $\varepsilon_{1}$

$\varepsilon_{0,4 f^{\prime c}}=$ Regangan aksial saat $0,4 \mathrm{fc}$

$\mathrm{w}_{\mathrm{c}} \quad=$ Berat volume beton $\left(\mathrm{kg} / \mathrm{m}^{3}\right)$

Mikrostruktur beton dapat dianalisis melalui pengujian Surface Area Anakysis (SAA) yang bertujuan untuk mencari nilai luas permukaan, volume pori dan radius pori suatu material. Nilai volume pori ini berkaitan dengan tingkat porositas beton dan kepadatan beton.

\section{METODE}

Metode yang digunakan dalam penelitian ini menggunakan metode eksperimental. Penelitian dilakukan secara bertahap mulai dari pengujian kuat desak beton, pengujian modulus elastisitas dan pengujian surface area analysis (SAA). Pengujian dilakukan pada umur beton ke-7, 14, 21 dan 28 hari. Benda uji yang digunakan berbentuk silinder dengan diameter $7,5 \mathrm{~cm}$ dan tinggi $15 \mathrm{~cm}$. Parameter yang harus diperhatikan dalam penelitian ini adalah nilai kuat desak rencana harus lebih dari $41,4 \mathrm{MPa}$ (syarat minimal beton mutu tinggi) dan kadar penggunaan bahan tambah accelerator adalah sebesar $2 \%$ dari berat semen. Kode dan jumlah benda uji yang digunakan dapat dilihat pada Tabel 1.

Tabel 1. Kode dan Jumlah Benda Uji

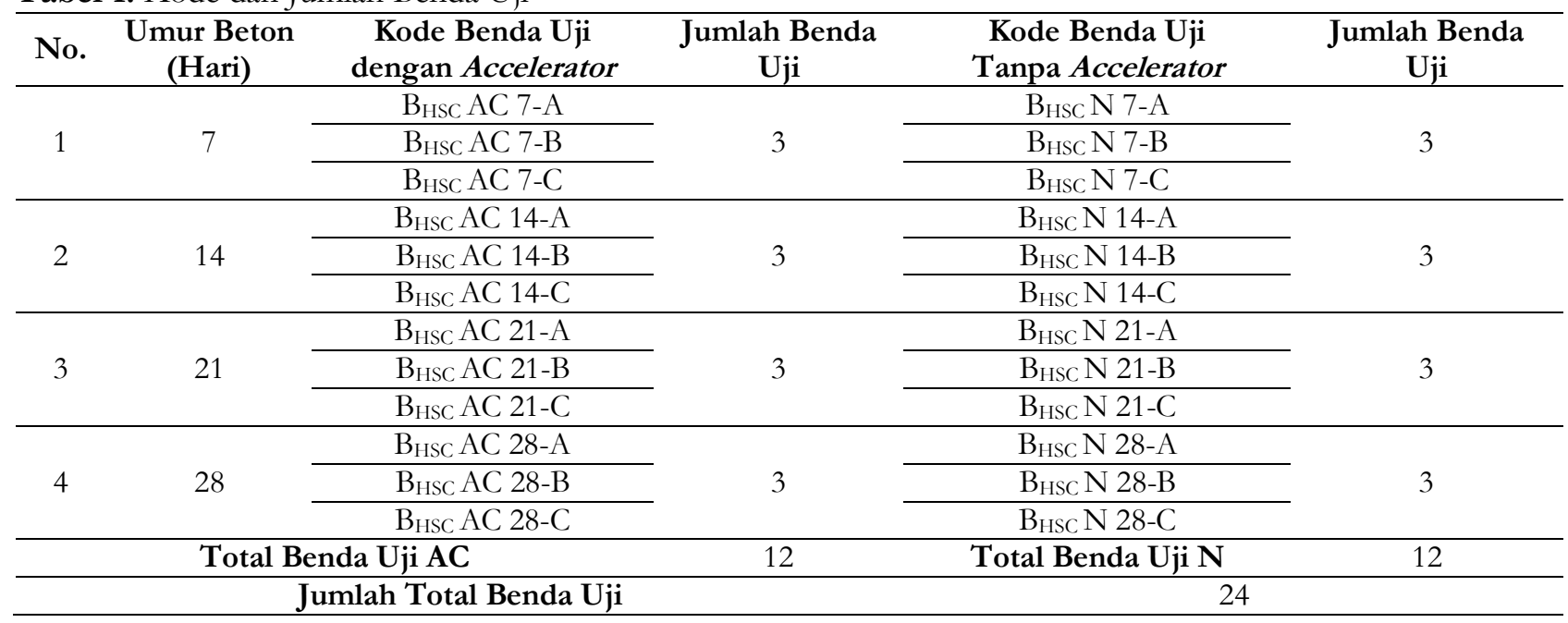

Pengujian beton segar yang dilakukan adalah uji slump. Kemudian, perawatan benda uji (curing) yang dilakukan dalam penelitian ini adalah dengan cara merendam benda uji yang telah berumur 1 hari $(24$ jam) ke dalam bak curing. Selanjutnya untuk beton keras dilakukan uji kuat desak dan modulus elastisitas dengan alat universal testing machine (UTM). Sementara itu, uji mikrostruktur dilakukan dengan alat surface area analyzer. Alat uji kuat desak, modulus elastisitas dan mikrostruktur yang digunakan dapat dilihat pada Gambar 1. 


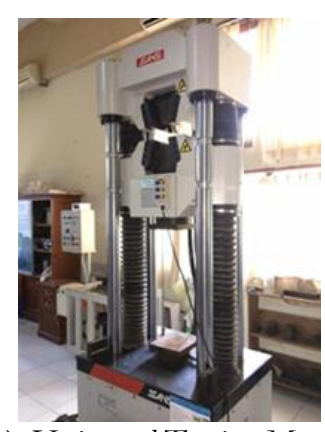

(a) Universal Testing Machine

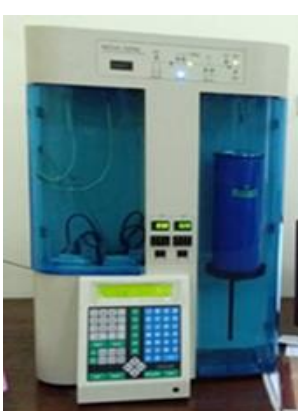

(b) Surface Area Analyzer

HASIL DAN PEMBAHASAN

Gambar 1. Alat Uji yang Digunakan

Rancang Campur (Mix Design)

Komposisi material penyusun beton normal tanpa bahan tambah accelerator $\left(\mathrm{B}_{\mathrm{HSC}} \mathrm{N}\right)$ dan beton dengan bahan tambah accelerator kadar $2 \%$ (B $\mathrm{B}_{\mathrm{HSC}} \mathrm{AC}$ ) yang digunakan per $1 \mathrm{~m}^{3}$ beton dapat dilihat pada Tabel 2.

Tabel 2. Rancang Campur Beton per $1 \mathrm{~m}^{3}$

\begin{tabular}{ccccccc}
\hline Beton & $\begin{array}{c}\text { Agregat Kasar } \\
\left(\mathbf{K g} / \mathbf{m}^{3}\right)\end{array}$ & $\begin{array}{c}\text { Agregat Halus } \\
\left(\mathbf{K g} / \mathbf{m}^{3}\right)\end{array}$ & $\begin{array}{c}\text { Semen } \\
\left(\mathbf{K g} / \mathbf{m}^{3}\right)\end{array}$ & $\begin{array}{c}\text { Accelerator } \\
\left(\mathbf{l t} / \mathbf{m}^{3}\right)\end{array}$ & $\begin{array}{c}\text { Air } \\
\left(\mathbf{l t} / \mathbf{m}^{3}\right)\end{array}$ & $\begin{array}{c}\text { Admixture } \\
\left(\mathbf{l t} / \mathbf{m}^{3}\right)\end{array}$ \\
\hline $\mathrm{B}_{\mathrm{HSC}} \mathrm{N}$ & 991,98 & 780,67 & 550 & 0 & 123,75 & 7,15 \\
\hline $\mathrm{B}_{\mathrm{HSC}} \mathrm{AC}$ & 984,48 & 774,76 & 539 & 11 & 123,75 & 7,15 \\
\hline
\end{tabular}

\section{Hasil Pengujian Slump}

Hasil pengujian slump untuk beton normal tanpa bahan tambah accelerator $\left(\mathrm{B}_{\mathrm{HSC}} \mathrm{N}\right)$ dan beton dengan bahan tambah accelerator kadar 2\% (B $\left.\mathrm{BSC}_{\mathrm{HC}} \mathrm{AC}\right)$ dapat dilihat pada Tabel 2.

Tabel 2. Hasil Penguiian Slump

\begin{tabular}{cc}
\hline Beton & Nilai $\operatorname{Slump}(\mathbf{c m})$ \\
\hline $\mathrm{B}_{\mathrm{HSC}} \mathrm{N}$ & 12 \\
\hline $\mathrm{B}_{\mathrm{HSC}} \mathrm{AC}$ & 11,5 \\
\hline
\end{tabular}

Nilai slump beton pada Tabel 2 untuk beton normal tanpa bahan tambah accelerator $\left(\mathrm{B}_{\mathrm{HSC}} \mathrm{N}\right)$ dan beton dengan bahan tambah accelerator kadar 2\% (B $\mathrm{BSC}_{\mathrm{HC}} \mathrm{AC}$ ) memenuhi nilai slump (untuk plat, balok, kolom, dinding) yang telah direncanakan sebelumnya sebesar 7,5 - $15 \mathrm{~cm}$ (Tjokrodimulyo,1992).

\section{Hasil Pengujian Kuat Desak}

Rekapitulasi hasil pengujian kuat desak untuk beton normal tanpa bahan tambah accelerator $\left(\mathrm{B}_{\mathrm{HSC}} \mathrm{N}\right)$ dan beton dengan bahan tambah accelerator kadar 2\% (B $\left.\mathrm{B}_{\mathrm{HSC}} \mathrm{AC}\right)$ dapat dilihat pada Tabel 3.

Tabel 3. Rekapitulasi Hasil Pengujian Kuat Desak

\begin{tabular}{|c|c|c|c|}
\hline Umur & Beton & $\begin{array}{c}\text { Kuat Desak } \\
(\mathrm{MPa})\end{array}$ & Persentase Kenaikan Kuat Desak (\%) \\
\hline \multirow[b]{2}{*}{7 Hari } & $\mathrm{B}_{\mathrm{HSC}} \mathrm{N}$ & 31,75 & \multirow{2}{*}{26,08} \\
\hline & $\mathrm{B}_{\mathrm{HSC}} \mathrm{AC}$ & 40,03 & \\
\hline \multirow{2}{*}{14 Hari } & $\mathrm{B}_{\mathrm{HSC}} \mathrm{N}$ & 34,64 & \multirow[b]{2}{*}{21,71} \\
\hline & $\mathrm{B}_{\mathrm{HSC}} \mathrm{AC}$ & 42,17 & \\
\hline \multirow{2}{*}{21 Hari } & $\mathrm{B}_{\mathrm{HSC}} \mathrm{N}$ & 39,74 & \multirow{2}{*}{17,49} \\
\hline & $\mathrm{B}_{\mathrm{HSC}} \mathrm{AC}$ & 46,69 & \\
\hline \multirow{2}{*}{28 Hari } & $\mathrm{B}_{\mathrm{HSC}} \mathrm{N}$ & 42,59 & \multirow{2}{*}{28,49} \\
\hline & $\mathrm{B}_{\mathrm{HSC}} \mathrm{AC}$ & 54,73 & \\
\hline
\end{tabular}

Pada umur 7 hari, nilai kuat desak beton dengan bahan tambah accelerator $2 \%$ sudah lebih tinggi dari nilai kuat desak beton tanpa bahan tambah dengan persentase kenaikan sebesar 26,08\%. Hal ini sesuai dengan pernyataan Wisnumurti dkk (2007), dimana penggunaan penggunaan dosis yang optimal dari accelerator yaitu antara 2\% - 5\% akan memberikan pengaruh peningkatan kuat desak beton pada umur-umur awal. Peningkatan nilai kuat desak beton dengan penambahan accelerator dapat ditinjau dari sifat accelerator itu sendiri, yaitu mempercepat waktu setting atau pengikatan dan memiliki kekuatan awal serta kuat desak yang tinggi. Pada umur 7 hari, beton dengan bahan 
tambah accelerator ( $\mathrm{B}_{\mathrm{HSC}} \mathrm{AC}$ ) belum dapat dikatakan sebagai beton mutu tinggi, namun pada umur 14, 21 dan 28 hari, beton dengan bahan tambah accelerator $\left(\mathrm{B}_{\mathrm{HSC}} \mathrm{AC}\right)$ sudah dapat dikatakan sebagai beton mutu tinggi karena nilai kuat desak yang dihasilkan sudah lebih dari 41,4 MPa.

Secara kimiawi, penambahan accelerator dapat mempercepat hidrasi dari $\mathrm{C}_{2} \mathrm{~S}$ dan $\mathrm{C}_{3} \mathrm{~S}$ yang merupakan senyawa dalam beton yang memiliki sifat perekat dikarenakan terdapat senyawa $\mathrm{CaCl}_{2}$ (kalsium klorida) dalam accelerator (Nugraha, 2007). Kalsium klorida berfungsi sebagai katalis atau segala sesuatu yang mengubah kecepatan reaksi tetapi bukan mengubah bagian dari reaksi itu pada proses hidrasi semen Portland (Dodson, 1990).

Hasil reaksi $\mathrm{C}_{2} \mathrm{~S}$ dan $\mathrm{C}_{3} \mathrm{~S}$ dengan air $\left(\mathrm{H}_{2} \mathrm{O}\right)$ adalah CSHprimer yang berfungsi sebagai perekat. Reaksi hidrasi semen dapat dilihat di bawah ini:
$\mathrm{C}_{3} \mathrm{~S}, \mathrm{C}_{2} \mathrm{~S}$
$+\mathrm{H}_{2} \mathrm{O}$
$\rightarrow$
$\mathrm{CSH}_{\text {primer }}$
$+\mathrm{Ca}(\mathrm{OH})_{2}$

Senyawa Semen + Air $\quad \rightarrow \quad$ Kalsium Silikat Hidrat + Kalsium Hidroksida

Senyawa CSH atau Kalsium Silikat Hidrat merupakan bahan pengikat dari pasta semen untuk mengikat agregat. Mempercepat reaksi $\mathrm{C}_{2} \mathrm{~S}$ dan $\mathrm{C}_{3} \mathrm{~S}$ berarti mempercepat juga pembentukan dari $\mathrm{CSH}$, sehingga akan meningkatkan daya ikat pasta semen terhadap agregat dan juga menambah kekuatan lekatan di daerah Interfacial Transition Zone (ITZ) serta mengurangi porositas beton.

Kenaikan nilai kuat desak beton sejalan dengan pertambahan umur beton. Semakin bertambahnya umur beton maka nilai kuat desak beton akan semakin tinggi. Kenaikan nilai kuat desak beton ini berkaitan erat dengan proses hidrasi semen. Grafik hubungan kuat desak dengan umur beton dapat dilihat pada Gambar 2.

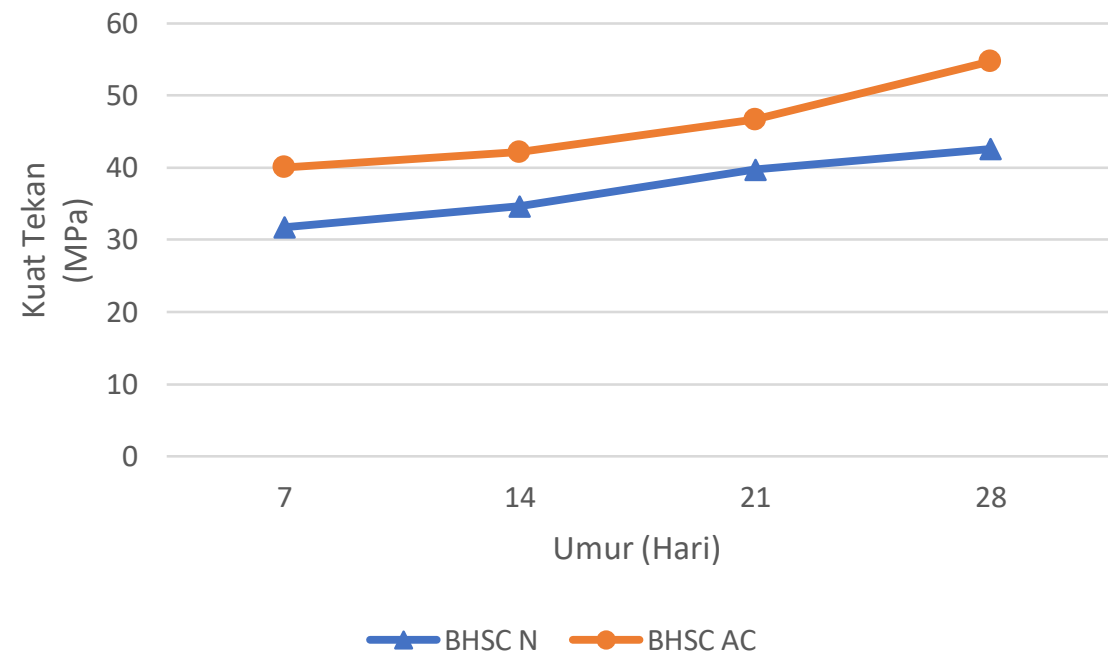

Gambar 2. Grafik Hubungan Kuat Desak dengan Umur Beton

\section{Hasil Pengujian Modulus Elastisitas}

Perhitungan nilai modulus elastisitas percobaan dilakukan menggunakan Persamaan [2] dan [3] dengan cara membaca grafik tegangan regangan. Sementara itu, perhitungan nilai modulus elastisitas teoritis dilakukan menggunakan Persamaan [4] dan [5]. Rekapitulasi hasil perhitungan modulus elastisitas percobaan dan teoritis untuk beton normal tanpa bahan tambah accelerator $\left(\mathrm{B}_{\mathrm{HSC}} \mathrm{N}\right)$ maupun beton dengan bahan tambah accelerator $\left(\mathrm{B}_{\mathrm{HSC}}\right.$ AC) umur 7, 14, 21, dan 28 hari dapat dilihat pada Tabel 4.

Tabel 4. Rekapitulasi Perhitungan Modulus Elastisitas

\begin{tabular}{cccccc}
\hline \multirow{2}{*}{ Umur } & \multirow{2}{*}{ Beton } & \multicolumn{2}{c}{ Ec Percobaan (MPa) } & Ec Perhitungan (MPa) \\
\cline { 3 - 6 } & & $\begin{array}{c}\text { Eurocode 2- } \\
\mathbf{1 9 9 2}\end{array}$ & ASTM C469 & ACI Committee 363- & \multirow{2}{*}{ SNI 2847-2013 } \\
\hline \multirow{2}{*}{7 Hari } & $\mathrm{B}_{\mathrm{HSC}} \mathrm{N}$ & 24760,17 & 25436,67 & 25607,00 & 29806,81 \\
\cline { 2 - 6 } & $\mathrm{B}_{\mathrm{HSC}} \mathrm{AC}$ & 28613,40 & 29567,00 & 27902,88 & 33193,23 \\
\hline \multirow{2}{*}{14 Hari } & $\mathrm{B}_{\mathrm{HSC}} \mathrm{N}$ & 27944,10 & 28173,00 & 26439,82 & 31133,78 \\
\cline { 2 - 6 } & $\mathrm{B}_{\mathrm{HSC}} \mathrm{AC}$ & 29941,35 & 30725,67 & 28457,74 & 34070,14 \\
\hline \multirow{2}{*}{21 Hari } & $\mathrm{B}_{\mathrm{HSC}} \mathrm{N}$ & 31794,25 & 29576,67 & 27828,15 & 33345,88 \\
\cline { 2 - 6 } & $\mathrm{B}_{\mathrm{HSC}} \mathrm{AC}$ & 32576,36 & 33398,00 & 29585,26 & 35852,08 \\
\hline \multirow{2}{*}{28 Hari } & $\mathrm{B}_{\mathrm{HSC}} \mathrm{N}$ & 31968,00 & 31497,00 & 28567,25 & 34523,54 \\
\hline
\end{tabular}




\begin{tabular}{lllll}
\hline $\mathrm{B}_{\mathrm{HSC}} \mathrm{AC}$ & 35691,03 & 36234,00 & 31459,73 & 38814,53 \\
\hline
\end{tabular}

Berdasarkan Tabel 4, dapat dilihat bahwa nilai modulus elastisitas hasil percobaan maupun perhitungan teoritis beton dengan bahan tambah accelerator $\left(\mathrm{B}_{\mathrm{HSC}} \mathrm{AC}\right)$ pada umur ke 7 hari sudah lebih tinggi dari beton normal tanpa bahan tambah accelerator $\left(\mathrm{B}_{\mathrm{HSC}} \mathrm{N}\right)$. Hal ini disebabkan karena pengaruh penambahan accelerator akan mempercepat proses hidrasi $\mathrm{C}_{2} \mathrm{~S}$ dan $\mathrm{C}_{3} \mathrm{~S}$ sehingga beton akan lebih cepat mengalami pengerasan dan lebih padat. Grafik hasil perhitungan modulus elastisitas beton pada umur 28 hari dapat dilihat pada Gambar 3.

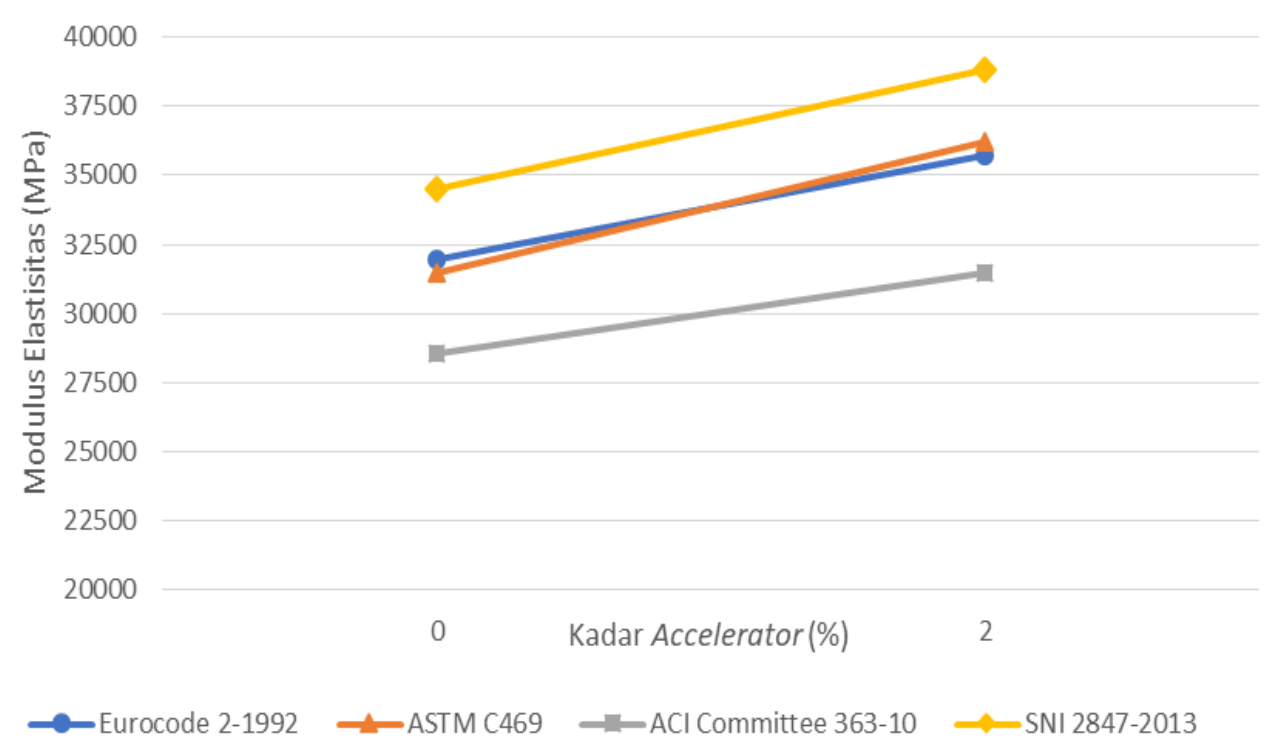

Gambar 3. Grafik Modulus Elastisitas Percoaban dan Teoritis Umur 28 Hari

\section{Hasil Pengujian Surface Area Analysis (SAA)}

Pengujian surface area analysis (SAA) dilakukan untuk sampel beton umur 7, 14, 21 dan 28 hari. Pengujian dilakukan dengan alat surface area analyzer. Sampel yang diuji berbentuk serbuk pasta yang berasal dari pecahan sampel beton yang sebelumnya telah dilakukan uji kuat desak dan sudah ditumbuk hingga sampel lolos ayakan no. $50(0,3 \mathrm{~mm})$.

Rekapitulasi hasil pengujian surface area analysis untuk beton normal tanpa bahan tambah accelerator ( $\mathrm{B}_{\mathrm{HSC}} \mathrm{N}$ ) maupun beton dengan bahan tambah accelerator $\left(B_{\mathrm{HSC}} \mathrm{AC}\right)$ umur 7, 14, 21, dan 28 hari dapat dilihat pada Tabel 5. Tabel 5. Rekapitulasi Hasil Pengujian Surface Area Analysis (SAA)

\begin{tabular}{ccccc}
\hline \multirow{2}{*}{ Umur } & Beton & $\begin{array}{c}\text { Radius Pori } \\
(\mathbf{A})\end{array}$ & $\begin{array}{c}\text { Volume Pori } \\
\mathbf{( c c / g )}\end{array}$ & $\begin{array}{c}\text { Luas Permukaan } \\
\left(\mathbf{m}^{2} / \mathbf{g}\right)\end{array}$ \\
\hline \multirow{2}{*}{7 Hari } & $\mathrm{B}_{\mathrm{HSC}} \mathrm{N}$ & 18,23 & 0,029 & 22,10 \\
\cline { 2 - 5 } & $\mathrm{B}_{\mathrm{HSC}} \mathrm{AC}$ & 18,17 & 0,024 & 19,17 \\
\cline { 2 - 5 } \multirow{2}{*}{14 Hari } & $\mathrm{B}_{\mathrm{HSC}} \mathrm{N}$ & 18,21 & 0,028 & 20,45 \\
& $\mathrm{~B}_{\mathrm{HSC}} \mathrm{AC}$ & 18,14 & 0,023 & 17,55 \\
\hline \multirow{2}{*}{21 Hari } & $\mathrm{B}_{\mathrm{HSC}} \mathrm{N}$ & 18,16 & 0,024 & 11,15 \\
\hline \multirow{2}{*}{28 Hari } & $\mathrm{B}_{\mathrm{HSC}} \mathrm{AC}$ & 18,10 & 0,021 & 11,97 \\
\cline { 2 - 5 } & $\mathrm{B}_{\mathrm{HSC}} \mathrm{N}$ & 18,12 & 0,022 & 9,67 \\
\hline
\end{tabular}

Berdasarkan Tabel 5, dapat dilihat hubungan antara luas permukaan dengan volume pori, yaitu dengan semakin bertambahnya umur beton normal tanpa bahan tambah accelerator $\left(\mathrm{B}_{\mathrm{HSC}} \mathrm{N}\right)$ dan beton dengan bahan tambah accelerator $\left(\mathrm{B}_{\mathrm{HSC}} \mathrm{AC}\right)$ maka, nilai luas permukaan dan nilai volume pori beton akan semakin menurun. Nilai luas permukaan yang menurun seiring dengan bertambahnya umur beton disebabkan karena pori yang terbentuk semakin berkurang dan beton menjadi semakin padat akibat proses hidrasi yang terjadi. Proses hidrasi ini melibatkan senyawa $\mathrm{C}_{2} \mathrm{~S}$ dan $\mathrm{C}_{3} \mathrm{~S}$ yang bereaksi dengan air $\left(\mathrm{H}_{2} \mathrm{O}\right)$ dan membentuk senyawa CSH. Semakin banyak CSH 
yang terbentuk maka meningkatkan daya ikat pasta semen. Grafik perbandingan volume pori pasta beton $\mathrm{B}_{\mathrm{HSC}} \mathrm{N}$ dengan beton $\mathrm{B}_{\mathrm{HSC}} \mathrm{AC}$ dapat dilihat pada Gambar 4.

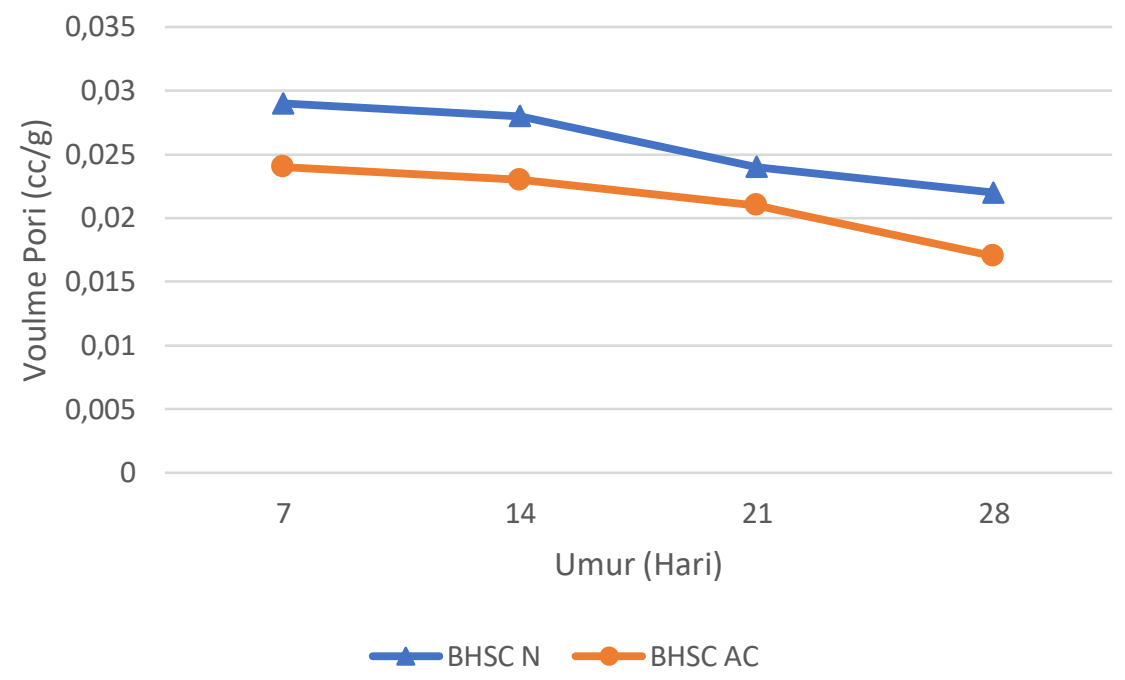

Gambar 4. Perbandingan Volume Pori antara Pasta Beton $\mathrm{B}_{\mathrm{HSC}} \mathrm{N}$ dan $\mathrm{B}_{\mathrm{HSC}} \mathrm{AC}$

Berdasarkan Gambar 4, dapat dilihat bahwa tingkat porositas pasta beton $\mathrm{B}_{\mathrm{HSC}}$ AC lebih kecil dibandingkan dengan beton $\mathrm{B}_{\mathrm{HSC}} \mathrm{N}$ di semua umur ditunjukkan dengan nilai volume pori $(\mathrm{cc} / \mathrm{g})$ yang dihasilkan. Persentase penurunan nilai volume pori antara beton $\mathrm{B}_{\mathrm{HSC}} \mathrm{N}$ dengan beton $\mathrm{B}_{\mathrm{HSC}} \mathrm{AC}$ adalah sebesar 17,24\% pada umur 7 hari; $17,86 \%$ pada umur 14 hari; $12,50 \%$ pada umur 21 hari dan 22,73\% pada umur 28 hari. Daya ikat pasta semen yang meningkat akan memperkecil rongga-rongga yang ada di dalam beton sehingga beton menjadi lebih padat. Dengan tingkat porositas yang rendah dan kerapatan yang tinggi maka akan berpengaruh pada sifat mekanik beton, yaitu kuat desak dan modulus elastisitas. Hubungan volume pori dengan kuat desak dan modulus elastisitas beton dapat dilihat pada Gambar 5 dan Gambar 6.

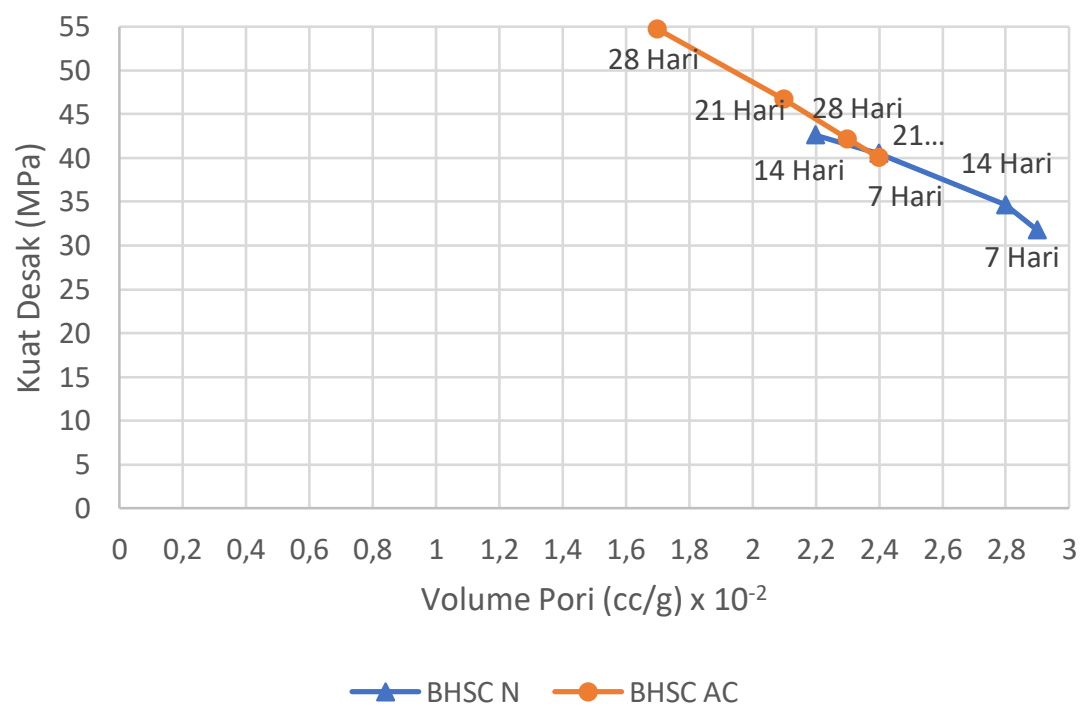

Gambar 5. Hubungan Volume Pori dengan Kuat Desak Beton $\mathrm{B}_{\mathrm{HSC}} \mathrm{N}$ dan $\mathrm{B}_{\mathrm{HSC}} \mathrm{AC}$ 


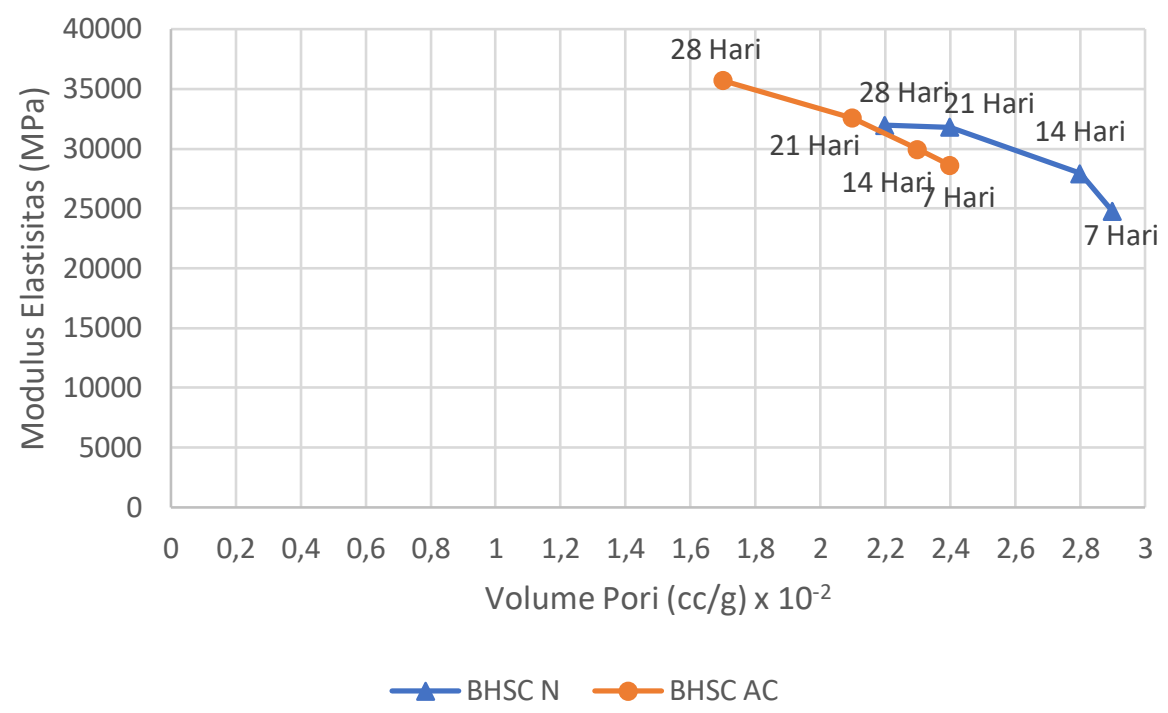

Gambar 6. Hubungan Volume Pori dengan Modulus Elastisitas (Eurocode 2-1992) Beton $\mathrm{B}_{\mathrm{HSC}} \mathrm{N}$ dan $\mathrm{B}_{\mathrm{HSC}} \mathrm{AC}$

\section{KESIMPULAN}

Berdasarkan hasil pengujian dan analisis yang dilakukan, dapat diambil kesimpulan sebagai berikut:

1. Kuat desak beton dengan bahan tambah accelerator ( $\mathrm{B}_{\mathrm{HSC}} \mathrm{AC}$ ) mendapatkan nilai yang lebih tinggi daripada beton tanpa bahan tambah $\left(\mathrm{B}_{\mathrm{HSC}} \mathrm{N}\right)$. Persentase kenaikan kuat desak rata-rata antara beton $\mathrm{B}_{\mathrm{HSC}} \mathrm{AC}$ dan $\mathrm{B}_{\mathrm{HSC}}$ $\mathrm{N}$ pada umur 7, 14, 21 dan 28 hari masing-masing adalah sebesar 26,08\%;21,71\%; 17,49\% dan 28,49\%. Sementara itu, nilai volume pori (cc/g) beton dengan bahan tambah accelerator $\left(\mathrm{B}_{\mathrm{HSC}} \mathrm{AC}\right)$ lebih kecil daripada beton tanpa bahan tambah $\left(\mathrm{B}_{\mathrm{HSC}} \mathrm{N}\right)$ dengan persentase penurunan pada umur 7, 14, 21 dan 28 masingmasing adalah sebesar $17,24 \% ; 17,86 \% ; 12,50 \%$ dan $22,73 \%$.

2. Beton dengan bahan tambah accelerator $\left(\mathrm{B}_{\mathrm{HSC}} \mathrm{AC}\right)$ memiliki nilai modulus elastisitas yang lebih tinggi daripada beton tanpa bahan tambah ( $\left.\mathrm{B}_{\mathrm{HSC}} \mathrm{N}\right)$. Persentase peningkatan nilai modulus elastisitas beton pada umur 7, 14, 21 dan 28 hari masing-masing adalah sebesar 8,97\%; 7,63\%; 6,31\% dan 10,13\%. Sementara itu, nilai volume pori $\left(\mathrm{cc} / \mathrm{g}\right.$ ) beton dengan bahan tambah accelerator $\left(\mathrm{B}_{\mathrm{HSC}} \mathrm{AC}\right)$ lebih kecil daripada beton tanpa bahan tambah $\left(\mathrm{B}_{\mathrm{HSC}} \mathrm{N}\right)$ dengan persentase penurunan pada umur 7, 14, 21 dan 28 masing-masing adalah sebesar 17,24\%; $17,86 \% ; 12,50 \%$ dan $22,73 \%$.

\section{UCAPAN TERIMAKASIH}

Terimakasih kepada Laboratorium Bahan Program Studi Teknik Sipil Fakultas Teknik Universitas Sebelas Maret Surakarta yang telah menyediakan sarana dan prasarana dalam penelitian ini.

\section{REFERENSI}

Anonim. 2000. Tata Cara Perencanaan Campuran Tinggi dengan Semen Portland dengan Abu Terbang (SNI 03-64682000). Badan Standarisasi Nasional. Jakarta Pusat.

Anonim. 2011. Cara Uji Kuat Tekan Beton dengan Benda Uji Silinder (SNI 1974-2011). Badan Standarisasi Nasional. Jakarta Pusat.

Anonim. 2013. Persyaratan Beton Struktural untuk Bangunan Gedung (SNI 2847-2013). Badan Standarisasi Nasional. Jakarta Pusat.

Anonim. 2017. SikaCim Accelerator. Product Data Sheet PT. Sika Indonesia. Jakarta.

Hapsari, Wahyu. 2018. Pengaruh Kadar Accelerator terhadap Kuat Tekan Pada High Strength Self Compacting Concrete (HSSCC) Benda Uji Silinder Umur 3, 7, 14, dan 28 Hari. Jurnal Program Studi Teknik Sipil Fakultas Teknik Universitas Sebelas Maret. Surakarta.

Mulyono, T. 2004. Teknologi Beton. Penerbit Andi Offset. Yogyakarta.

Murdock, L. J. dan Brook, K. M. 1999. Concrete Materials and Practice. Penerbit Erlangga. Jakarta.

Nugraha, P. dan Antoni. 2007. Teknologi Beton dari Material. Pembuatan, ke Beton Kinerja Tinggi. Penerbit Andi Offset, Yogyakarta. 
Tjokrodimulyo, K. 1992. Teknologi Beton. Biro Penerbit Jurusan Teknik. Yogyakarta.

Wisnumurti, dkk. 2007. Pengaruh Penggunaan Akselerator Megaset Merah di Bawah Dosis Optimal Terhadap Kuat Tekan Beton dengan Berbagai V ariasi Umur Beton. Jurnal Rekayasa Sipil Vol. 1. Malang. 